\title{
Terapi Aktivitas Kelompok Stimulasi Persepsi Pada Pasien Halusinasi Di Yayasan Pemenang Jiwa Sumatera
}

\author{
Elis Melina Br Manullang, Emma Pratiwi Manik, Teuku Hamdi, \\ Monalisa, Shintiya Putri Tarigan
}

\section{emelinamanullang@gmail.com}

\begin{abstract}
Abstrak
Halusinasi merupakan distorsi persepsi palsu yang terjadi pada respon neurobiologist maladaptive, penderita sebenarnya mengalami distorsi sensori sebagai hal yang nyata dan meresponnya. Upaya yang dilakukan untuk menangani klien halusinasi adalah dengan memberikan tidakan keperawatan yaitu terapi aktivitas kelompok. Terapi aktivitas kelompok merupakan salah satu terapi modalitas yang dapat membantu membangun hubungan dengan orang lain, dengan terapi aktivitas kelompok, pasien dapat bersosialisasi, mengetahui koteks realitas, menyalurkan energi, meningkatkan harga diri. Pasien yang mengikuti kegiatan berjumlah 5 orang dari Yayasan Pemenang Jiwa. Setelah mendapatkan terapi aktivitas kelompok stimulasi persepsi sensori (halusinasi), pasien menunjukkan adanya peningkatan pengetahuan, pemahaman tentang cara mengontrol halusinasi dan tahu bagaimana cara melakukannya. Peningkatan pengetahuan diketahui bahwa pasien mampu mengingat SP 1-4 dari permainan terapi aktivitas kelompok. Diharapkan bagi pasien yang mengalami masalah halusinasi kedepannya mampu melakukan tindakan stimulasi persepsi secara mandiri.
\end{abstract}




\section{BAB 1 \\ PENDAHULUAN}

\subsection{Latar Belakang}

Skizofrenia merupakan penyakit kronis, parah, dan melumpuhkan, gangguan otak yang ditandai dengan pikiran kacau, waham, delusi, halusinasi dan perilaku aneh atau katatonik. Skizofrenia merupakan suatu gangguan jiwa berat yang bersifat kronis yang ditandai dengan hambatan dalam berkomunikasi, gangguan realitas, afek tidak wajar atau tumpul, gangguan fungsi kognitif serta mengalami kesulitan dalam melakukan aktivitas seharihari (Pardede \& Laia., 2020). Masalah gangguan kesehatan jiwa di seluruh dunia sudah menjadi masalah yang serius. WHO memperkirakan sekitar 450 juta orang di dunia yang mengalami gangguan kesehatan jiwa, 135 juta orang diantaranya mengalami halusinasi. Diperkirakan penduduk Indonesia yang menderita gangguan jiwa sebesar 2-3\% jiwa, yaitu sekitar 1 sampai 1,5 juta jiwa diantaranya mengalami halusinasi (Aritonang, 2021).

Halusinasi merupakan distorsi persepsi palsu yang terjadi pada respon neurobiologist maladaptive, penderita sebenarnya mengalami distorsi sensori sebagai hal yang nyata dan meresponnya. Diperkirakan $\geq 90 \%$ penderita gangguan jiwa jenis halusinasi. dengan bentuk yang bervariasi tetapi sebagian besarnya mengalami halusinasi pendengaran yang dapat berasal dari dalam diri individu atau dari luar individu tersebut, suara yang didengar bisa dikenalnya, jenis suara tunggal atau multiple yang dianggapnya dapat memerintahkan tentang perilaku individu itu sendiri (Yanti, et al, 2020). Halusinasi juga merupakan salah satu gejala gangguan persepsi sensori yang dialami oleh pasien gangguan mental. biasanya penderita merasakan sensasi suara, penegelihatan, rasa, sentuhan, atau penciuman tanpa rangsangan yang nyata (Pardede, 2020). 
Pasien dengan diagnosis medis skizofrenia $90 \%$ pasien mengalami halusinasi. Dimana 70\% diantaranya mengalami halusinasi pendengaran, $20 \%$ mengalami halusinasi penglihatan dan $10 \%$ adalah halusinasi penghidu, pengacapan dan perabaan. Berdasarkan data tersebut diketahui bahwa jenis halusinasi yang paling banyak diderita oleh pasien dengan skizofren adalah halusinasi pendengaran (Hidayah, 2015). Halusinasi biasanya muncul sebagai dampak dari proses yang berkaitan dengan kepribadian seseorang. Karena itu, halusinasi dipengaruhi oleh pengalaman psikologis seseorang yang berdampak panjang karena tidak di tanganai dengan baik (Pardede \& Siregar, 2016).

Menurut Livana (2020) menyatakan bahwa dampak yang dapat ditimbulkan oleh pasien yang mengalami halusinasi adalah kehilangan kontrol dirinya. Pasien akan mengalami panik dan perilakunya dikendalikan oleh halusinasi. Pada situasi ini pasien dapat melakukan bunuh diri (suicide), membunuh orang lain (homicide), bahkan merusak lingkungan Untuk memperkecil dampak yang ditimbulkan halusinasi, dibutuhkan penanganan yang tepat. Dengan banyaknya angka kejadian halusinasi, semakin jelas bahwa dibutuhkan peran perawat untuk membantu pasien agar dapat mengontrol halusinasinya

Adapun gejala-gejala yang dapat diamati pada pasien halusinasi diantaranya bicara atau tertawa sendiri, marah-marah tanpa sebab, menunjuk ke arah tertentu, ketakutan pada sesuatu yang tidak jelas, mencium seperti sedang membaubauin sesuatu, menutup hidung. Halusinasi benar - benar nyata dirasakan oleh klien yang mengalaminya, seperti mimpi saat tidur. Klien mungkin tidak punya cara untuk menentukan persepsi tersebut nyata, sama halnya seseorang seperti seseorang yang mendengarkan siaran ramalan cuaca dan tidak lagi meragukan orang yang berbicara tentang cuaca tersebut. Ketidakmampuan untuk mempersepsikan stimulus secara riil dapat menyulitkan kehidupan klien. Karenanya halusinasi menjadi prioritas untuk segera diatasi (Putri, 2017). 
Upaya yang dilakukan untuk menangani klien halusinasi adalah dengan memberikan tidakan keperawatan yaitu membantu pasien mengenali halusinasi, isi halusinasi, waktu terjadi halusinasi, frekuensi terjadinya halusinasi, situasi yang menyebabkan halusinasi muncul dan respon klien saat halusinasi muncul. Kemuadian dengan melatih klien mengontrol halusinasi dengan menggunakan strategi pelaksanaanya itu dengan cara menghardik halusinasi, bercakap-cakap dengan orang lain, melakukan aktivitas yang terjadwal dan menggunakan obat secara teratur. Terapi aktivitas kelompok stimulasi persepsi yang bertujuan untuk meningkatkan kemampuan sensori, upaya memusatkan perhatian, kesegaran jasmani dan mengekspresikan perasaan. Penggunaan terapi kelompok dalam praktek keperawatan jiwa akan memberikan dampak positif dalam upaya pencegahan, pengobatan atau terapi serta pemulihan kesehatan. Terapi aktivitas kelompok stimulasi persepsi ini sebagai upaya untuk memotivasi proses berpikir, mengenal halusinasi, melatih pasien mengontrol halusinasi serta mengurangi perilaku mal adaptif (Sutinah, et al, 2020).

Terapi aktivitas kelompok merupakan salah satu terapi modalitas yang dilakukan perawat kepada sekelompok pasien yang mempunyai masalah keperawatan yang sama. Terapi aktivitas kelompok sudah sejak lama dimasukkan dalam program terapi keperawatan di dunia yang merupakan salah satu dari interpensi keperawatan yang diprogramkan terhadap pasien jiwa skizoprenia dengan masalah pasien yang mengalami halusinasi (Ningsih, Murtiani \& Ilyas, 2013).

Berdasarkan hasil survey awal yang dilakukan di Yayasan Pemenang Jiwa Sumatera bahwa pasien yang mengalamai gangguan jiwa sebanyak 70 orang, tetapi yang menjadi subjek di dalam pelaksanaan Terapi Aktivitas Kelompok adalah 5 orang dengan halusinasi pendengaran. Hasil wawancara menunjukkan bahwa pasien belum penah mengikuti Terapi Aktivitas Kelompok selama berada di yayasan tersebut. Oleh sebab itu kelompok tertarik untuk melakukakan terapi aktivitas kelompok stimulus perepsi. 


\subsection{Tujuan Umum}

Setelah mengikuti kegiatan ini Pasien dapat lebih menerapkan strategi pelaksanaan Halusinasi secara fisik dan sosial dalam mengontrol Halusinasi.

\subsection{Tujuan Khusus}

Pasien dapat mengendalikan halusinasi sesuai strategi pelaksanaan (SP)

1. Pasien dapat mengidentifikasi isi, frekuensi, waktu terjadi, situasi pencetus dan respon halusinasi.

2. Pasien dapat mengontrol halusinasi dengan menghardik

3. Pasien dapat mengontrol halusinasi dengan minum obat secara teratur

4. Pasien dapat mengontrol halusinasi dengan bercakap-cakap dengan orang lain

5. Pasien dapat mengontrol halusinasi dengan melakukan kegiatan terjadwal. 


\section{BAB 2}

\section{STANDAR PELAKSANAAN TERAPI AKTIVITAS KELOMPOK}

STIMULASI PRESEPSI PADA PASIEN HALUSINASI

\subsection{Metode Terapi Aktifitas Kelompok (TAK)}

Metode yang digunakan pada terapi aktifitas kelompok (TAK) ini adalah metode :

1. Perkenalan diri pada seluruh perawat

2. Menanyakan perasaan klien pada saat terapi berjalan

\subsection{Waktu dan Tempat}

Hari/tanggal : Jumat, 19 Maret 2021

Jam : 10.00 WIB

Tempat $\quad$ : $\quad$ Ruang Pertemuan Yayasan Pemenang Jiwa

\subsection{Peserta TAK}

Pasien yang mengikuti kegiatan berjumlah 5 orang dari pasien Yayasan Pemenang Jiwa terdiri dari:

1. Ny. S (24 th)

2. Ny. P (54 th)

3. Tn. Y (56 th)

4. Tn. A (54 th)

5. Ny. M (33 th)

\subsection{Media dan Alat}

1. Handphone

2. Speaker

3. Music/lagu

4. Buku catatan dan pulpen

5. Jadwal kegiatan pasien

6. Kotak Korek Api

7. Gambar Hewan dan Buah - Buahan 


\subsection{Susunan Pelaksanaan}

Yang bertugas dalam TAK kali ini di sesuaikan dengan petugas setiap sesi yang telah disepakati sebagai berikut :

- Leader : Elis Melina Br Manullang, S. Kep

- Co.Leader : Shintiya Putri Br Tarigan, S. Kep

- Fasilitator 1 : Teuku Hamdi, S. Kep

- Fasilitator 2 : Emma Pratiwi Manik, S. Kep

- Observer $\quad$ : Monalisa Sianturi, S. Kep

\subsection{Uraian Tugas Pelaksana}

1. Leader :

a) Menyampaikan tujuan dan peraturan kegiatan terapi aktivitas kelompok menyiapkan proposal kegiatan TAK

b) Mampu memotivasi anggota untuk aktif dalam kelompok dan memperkenalkan dirinya

c) Mampu memimpin terapi aktivitas kelompok dengan baik dan tertib Menetralisir bila ada masalah yang timbul dalam kelompok

2. Co.Leader :

a) Mendampingi Leader

b) Menjelaskan aturan permaian

c) Menyampaikan informasi dari fasilitator ke leader tentang aktivitas klien

d) Mengingatkan leader jika kegiatan menyimpang dari perencanaan yang telah di buat

e) Mengambil alih posisi leader jika leader mengalami blocking dalam proses terapi

3. Fasilitator :

a) Menyediakan fasilitas selama kegiatan berlangsung Ikut serta dalam kegiatan kelompok

b) Memfasilitasi dan memberikan stimulus dan motivator pada anggota kelompok untuk aktif mengikuti jalannya terapi 
4. Observer :

a) Mengobservasi jalannya proses kegitan

b) Mengamati serta mencatat perilaku verbal dan non verbal pasien selama kegiatanberlangsung (dicatat pada format yang tersedia)

c) Mengawasi jalannya aktivitas kelompok dari mulai persiapan, proses , hingga penutupan

d) Memberikan hadiah (reward) bagi pasien yang menang dalam permainan.

\subsection{Kriteria Pasien}

1. Pasien dengan Halusinasi yang sudah kooperatif

2. Pasien yang tidak mengalami gangguan komunikasi verbal

3. Pasien bisa tulis dan baca

4. Pasien yang bersedia mengikuti TAK

\subsection{Antisipasi masalah}

1. Sebelum kegiatan dilaksanakan, perawat memberi kesempatan kepada setiap peserta untuk ke toilet

2. Fasilitator memotivasi peserta yang tidak berpartisipasi

3. Menjaga pintu keluar unuk mengantisipasi klien melarikan diri dari tempat kegiatan

\subsection{Langkah-langkah Kegiatan}

\section{Persiapan}

a) Membuat kontrak dengan anggota kelompok

b) Mempersiapkan alat dan tempat pertemuaan

\section{Orientasi}

a) Salam teraupetik

Salam dari leader kepada klien. Leader/Co Leader memperkenalkan diri dan tim terapis lainnya. 
b) Evaluasi/Vasilidasi

Leader menanyakan perasaan dan keadaan klien saat ini.

c) Kontrak

1) Menjelaskan tujuan kegiatan

2) Menjelaskan aturan main yaitu :

a. Berkenalan dengan anggota kelompok

b. Jika ada peserta yang akan meninggalkan kelompok, harus minta izin pada pemimpin TAK

c. Lama Kegiatan 45 menit

d. Setiap pasien mengikuti kegiatan dari awal sampai akhir

\section{Tahap Kerja}

a) Seluruh klien dibuat berbentuk lingkaran

b) Hidupkan music dan edarkan kotak korek api sesuai dengan arah jarum jam

c) Pada saat musik berhenti, anggota kelompok yang memegang kotak korek api, mendapat giliran untuk perkenalan dengan anggota kelompok yang ada di sebelah kanan dengan cara:

1) Memberi salam

2) Menyebutkan nama lengkap, nama panggilan, asal dan hobby.

3) Menanyakan nama lengkap, nama panggilan, asal dan hobby

4) Dimulai oleh terapis sebagai contoh.

d) Setelah memperkenalkan diri klien menebak gambar dan SP yang terdapat pada gambar tersebut. Klien akan bercerita sesuai gambar yang dipilih dan setelah itu memperagakan SP yang tyerdapat pada gambar tersebut.

e) Ulangi musik kembali, dan klien kembali mengoper kotak korek api, ketika musik berhenti, klien yang memegan kotak korek api, kembali memperagakan point $\mathrm{c}$ dan $\mathrm{d}$. 


\section{Tahap Terminasi}

a) Leader atau Co.Leader memberikan pujian atas keberhasilan dan kerjasama kelompok

b) Leader atau Co.Leader menanyakan perasaan klien setelah mengikuti kegiatan TAK

c) Fasilitator membagikan Snack

d) Leader atau Co.Leader menganjurkan klien untuk sering bersosialisasi, selalu bekerjasama, dan memasukkan kegiatan mengontrol Halusinasi ke dalam kegiatan harian sebanyak 2x1.

e) Observer mengumumkan pemenang

f) Fasilitator membagikan hadiah kepada pemenang

\section{Evaluasi}

a) Klien mengikuti kegiatan dari awal hingga akhir kegiatan

b) Kerja sama klien dalam kegiatan

c) Klien merasa senang selama mengikuti kegiatan

\subsection{Setting Tempat}

a) Terapis dan klien duduk bersama dalam lingkaran

b) Ruangan yang nyaman dan tenang

\subsection{Setting Tempat}

a) Terapis dan klien duduk bersama dalam lingkaran

b) Ruangan yang nyaman dan tenang

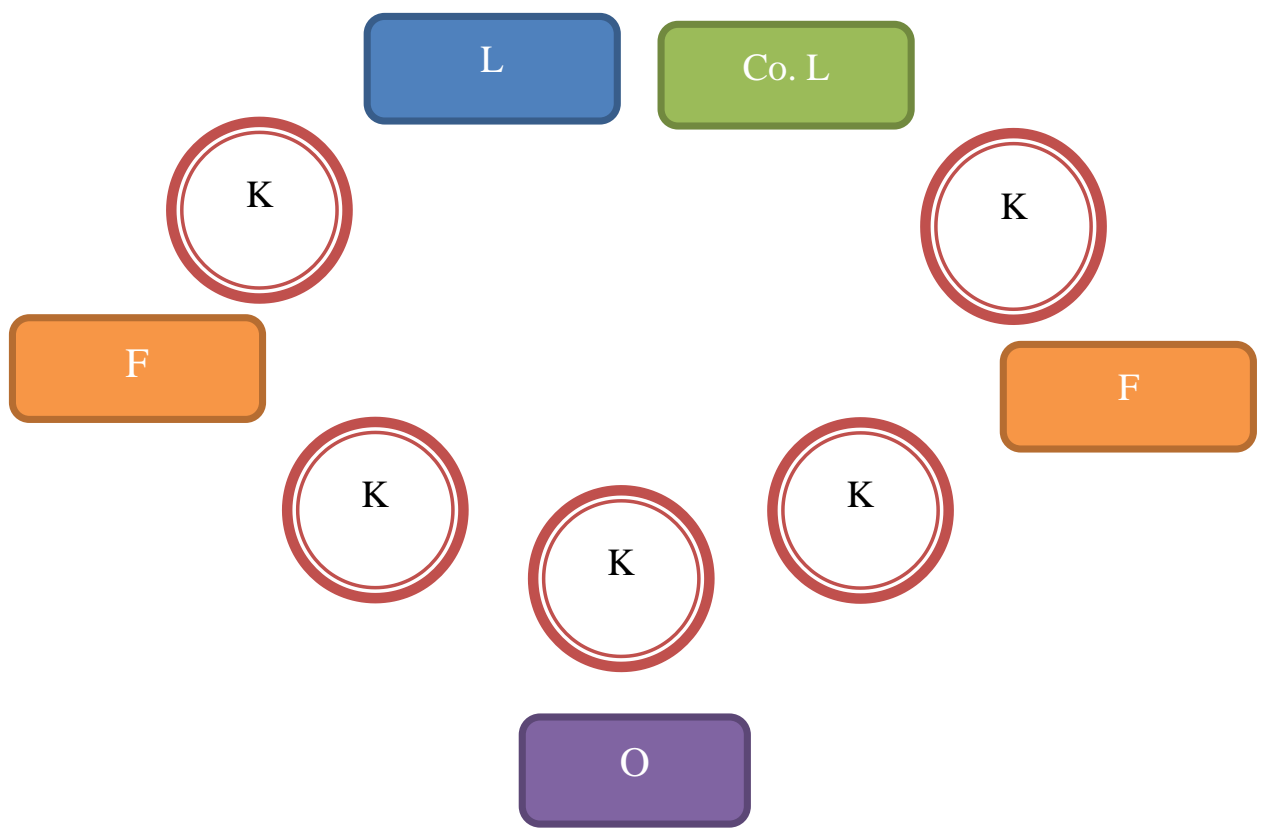


Keterangan Gambar:

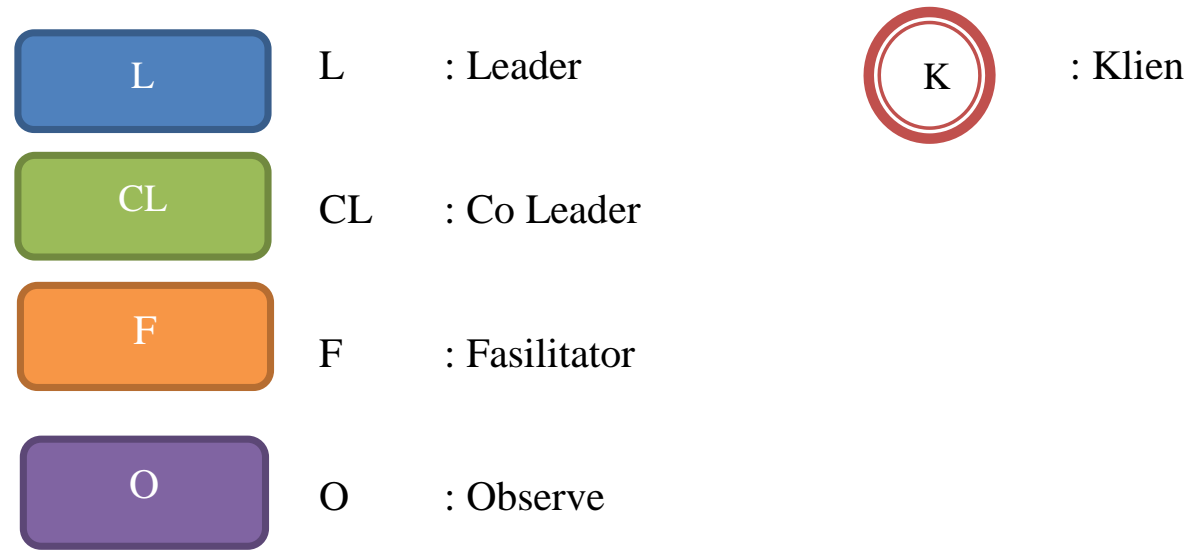

\subsection{Tata Tertib dan Antisipasi Masalah}

\section{Tata tertib pelaksanaan TAK Halusinasi}

a. Peserta bersedia mengikuti kegiatan TAK sampai dengan selesai

b. Peserta wajib hadir 5 menit sebelum acara TAK dimulai

c. Peserta berpakaian rapi, bersih, dan sudah mandi

d. Peserta tidak diperkenankan makan, minum, merokok selama kegiatan TAK berlangsung

e. Jika ingin mengajukan/menjawab pertanyaan, peserta mengangkat tangan kanan dan berbicara setelah dipersilahkan oleh pemimpin

f. Peserta yang mengacaukan jalannya acara akan dikeluarkan dari permainan

g. Peserta dilarang meninggalkan tempat sebelum acara TAK selesai

h. Apabila waktu yang ditentukan untuk melaksanakan TAK telah habis, sedangkan permainan belum selesai, maka pemimpin akan meminta persetujuan anggota untuk memperpanjang waktu TAK

\section{Antisipasi kejadian yang tidak diinginkan pada proses TAK}

Penanganan klien yang tidak efektif saat aktifitas kelompok

a. Memanggil klien

b. Memberi kesempatan kepada klien tersebut untuk menjawab sapaan perawat atau klienyang lain 


\section{Bila klien meninggalkan permainan tanpa pamit:}

a. Panggil nama klien

b. Tanya alasan klien meninggalkan permainan

c. Berikan penjelasan tentang tujuan permainan dan berikan penjelasan pada klien bahwaklien dapat melaksanakan keperluannya setelah itu klien boleh kembali lagi

\section{Bila ada klien lain ingin ikut}

a. Berikan penjelasan bahwa permainan ini ditujukan pada klien yang telah dipilih

b. Katakan pada klien lain bahwa ada permainan lain yang mungkin dapat diikuti oleh klien tersebut

c. Jika klien memaksa, beri kesempatan untuk masuk dengan tidak memberi peran pada permainan tersebut 


\section{BAB 3 \\ EVALUASI}

Kegiatan TAK dilaksanakan pada hari Jumat, 19 Maret 2021 Jam 10.00 WIB sesuai dengan rencana yang ada diproposal. Kegiatan dilakukan di Ruangan Yayasan Pemenang Jiwa Sumatera. Pasien berjumlah 5 orang peserta, laki-laki 3 orang dan perempuan 2 orang sesuai dengan proposal yang telah diajukan. Dalam terapi aktivitas kelompok perawat melakukan kontrak kepada pasien sehari sebelum TAK dilakukan. Mempersiapkan alat dan menyeting tempat dilakukan sebelum pasien datang di tempat pelaksanaan TAK.

Sebelum TAK dilaksanakan, leader memperkenalkan diri kepada pasien dan leader memberikan kesempatan untuk co-leader, fasilitator dan observer untuk memperkenalkan diri kepada pasien dan memberikan pasien kesempatan untuk memperkenalkan dirinya masing-masing. Leader dan co-leader saling bergantian menjelaskan peraturan terapi aktivitas kelompok, seperti bagiamana peraturan yang di buat saat terapi aktivitas kelompok dilaksanakan, durasi berjalannya terapi aktivitas kelompok dan memberikan infromasi kepada pasien bahwa perawat yang berada disebelah pasien sebagai fasilitator untuk membantu pasien selama berjalannya terapi aktivitas kelompok.

Dalam terapi aktivitas kelompok, leader dan co-leader sudah melakukan tugasnya untuk menjelaskan jalannya terapi aktivitas kelompok dan memimpin jalannya terapi. Fasilitator sudah melakukan tugasnya untuk membantu pasien selama berjalannya terapi aktivitas kelompok. Observer telah melakukan tugasnya dengan mengamati jalannya terapi aktivitas kelompok apakah pasien mampu melakukan SP yang sudah ditentukan terapis. 
Respon pasien saat diberikan terapi aktivitas kelompok yaitu :

1. Kemampuan Mengenal Halusinasi

Pasien mengatakan mendengar Suara saat menyandiri, suara muncul saat klien sedang sendiri.

2. Kemampuan Menghardik Halusinasi

Pasien mengatakan jika halusinasi muncul pasien berdoa dan menolak suara tersebut. Pasien memperagakan teknik meghardik.

3. Kemampuan Patuh Minum Obat

Pasien mengatakan minum obat $2 \mathrm{x} /$ hari. Pasien mengatakan keuntungan dengan minum obat yaitu suara-suara halusinasi tersebut hilang dan pasien bisa tidur dengan nyenyak.

4. Kemampuan Bercakap-cakap

Pasien mengatakan suka mengalihkan suara yang datang dengan mengobrol bersama teman satu kamarnya atau dengan teman yang didekatnya.

5. Kemampuan Membuat Jadwal Kegiatan

Pasien mengatakan melakukan kegiatan terjadwal dari pagi sampai malam, sesuai dengan aktivitas yang biasa dilakukan diyayasan pemenang jiwa sumatera utara 


\section{BAB 4 \\ PENUTUP}

\subsection{Kesimpulan}

Terapi aktivitas kelompok stimulasi persepsi halusinasi adalah terapi yang menggunakan aktivitas sebagai stimulus dan terkait dengan pengalaman dan atau kehidupan untuk didiskusikan dalam kelompok. Hasil diskusi kelompok dapat berupa kesepakatan persepsi atau alternatif penyelesaian masalah. Dalam terapi aktivitas kelompok stimulasi persepsi aktivitas yang digunakan adalah aktivitas mempersepsikan stimulus tidak nyata dan respon yang dialami dalam kehidupan, khususnya untuk klien mengalami halusinasi. Aktivitas dibagi dalam beberapa sesi yang tidak dapat dipisahkan yaitu, terapi aktivitas kelompok stimulasi persepsi mengenal halusinasi, terapi aktivitas kelompok stimulasi persepsi halusinasi mengusir atau menghardik halusinasi, terapi aktivitas kelompok stimulasi persepsi mengontrol halusinasi dengan melakukan kegiatan, terapi aktivitas kelompok stimulasi persepsi mengontrol halusinasi dengan bercakap - cakap dan terapi aktivitas kelompok stimulasi perepsi mengontrol halusinasi dengan patuh minum obat (Putri, 2017).

Terapi aktivitas kelompok merupakan salah satu terapi modalitas yang dapat membantu membangun hubungan dengan orang lain, dengan terapi aktifitas kelompok, pasien dapat bersosialisasi, mengetahui koteks realitas, menyalurkan energi, meningkatkan harga diri (Pardede \& Ramadia, 2021). Terapi aktivitas kelompok stimulasi persepsi yang bertujuan untuk meningkatkan kemampuan sensori, upaya memusatkan perhatian, kesegaran jasmani dan mengekspresikan perasaan. Penggunaan terapi kelompok dalam praktek keperawatan jiwa akan memberikan dampak positif dalam upaya pencegahan, pengobatan atau terapi serta pemulihan kesehatan. Terapi aktivitas kelompok stimulasi persepsi ini sebagai upaya untuk memotivasi proses berpikir, mengenal halusinasi, melatih pasien mengontrol halusinasi serta mengurangi perilaku mal adaptif (Sutinah, dkk, 2020). 
Setelah mendapatkan terapi aktivitas kelompok stimulasi persepsi sensori (halusinasi), pasien terapi aktivitas kelompok di yayasan pemenang jiwa sumatera utara terjadi peningkatan pengetahuan, pemahaman tentang cara mengontrol halusinasi dan tahu bagaimana cara melakukannya. Peningkatan pengetahuan diketahui bahwa pasien mampu mengingat SP 1-4 dari permainan terapi aktivitas kelompok.

\subsection{Saran}

Diharapkan bagi tenaga kesehatan menjadikan Terapi Aktivitas Kelompok stimulasi persepsi sebagai tindakan keperawatan untuk setiap pasien dengan masalah gangguan jiwa khusunya pasien Halusianasi karena menurut penelitian (Sutinah, dkk, tahun 2020) tentang terapi aktivitas kelompok stimulasi persepsi sensori (halusinasi) pada klien halusinasi didapatkan hasil bahwa setelah mendapatkan terapi aktivitas kelompok stimulasi persepsi sensori (halusinasi) klien halusinasi di rumah sakit jiwa provinsi jambi terjadi peningkatan pengetahuan, pemahaman tentang cara mengontrol halusinasi dan tahu bagaimana cara melakukannya. 


\section{DAFTAR PUSTAKA}

Aritonang, M. (2021). Efektifitas Terapi Aktivitas Kelompok Stimulasi Terhadap Kemampuan Mengontrol Halusinasi Pendengaran Pada Pasien Ruang Cempaka Di Rsj Prof. Dr. M. Ildrem Medan Tahun 2019. Jurkessutra: Jurnal Kesehatan Surya Nusantara, 9(1). https://jurnal.suryanusantara.ac.id/index.php/jurkessutra/article/view/64

Hidayah, A. N. (2015). Pengaruh Terapi Aktivitas Kelompok Stimulasi PersepsiSensori Terhadap Kemampuan Mengontrol Halusinasi Pada Pasien Halusinasi di RSJD dr. Amino Gondohutomo Semarang. FIKkeS, 8(1). https://jurnal.unimus.ac.id/index.php/FIKkeS/article/view/1900

Livana, P. H., Ruhimat, I. I. A., Sujarwoo, S., Suerni, T., Kandar, K., Maya, A., \& Nugroho, A. (2020). Peningkatan Kemampuan Pasien dalam Mengontrol Halusinasi melalui Terapi Aktivitas Kelompok Stimulasi Persepsi. Jurnal Ners Widya Husada, 5(1), 35-40. https://doi.org/10.33666/jners.v5i1.328

Ningsih, P., Murtiani, M., \& Ilyas, M. (2013). Pengaruh Terapi Aktivitas Kelompok Stimulasi Persepsi Terhadap Kemampuan Mengontrol Halusinasi Pada Pasien Halusinasi Di Ruang Kenanga Rumah Sakit Khusus Daerah Propinsi Sulawesi Selatan. Jurnal Ilmiah Kesehatan Diagnosis, 2(4), 28-34. http://ejournal.stikesnh.ac.id/index.php/jikd/article/view/440

Pardede, J. A (2020). Decreasing Hallucination Response Through Perception Stimulation Group Activity Therapy In Schizophrenia Patients. Iar Journal of Medical Sciences. 1(6), 304-309.

Pardede, J. A., \& Laia, B. (2020). Decreasing Symptoms of Risk of Violent Behavior in Schizophrenia Patients Through Group Activity Therapy. Jurnal Ilmu Keperawatan Jiwa, 3(3), 291-300. http://dx.doi.org/10.32584/jikj.v3i3.621

Pardede, J. A., \& Ramadia, A. (2021). The Ability to Interact With Schizophrenic Patients through Socialization Group Activity Therapy. International Journal of Health Science and Medical Research, 1(1), 06-10. http://ijhsmr.com/index.php/ijhsmr/article/view/6

Pardede, J. A., \& Siregar, R. A. (2016). Pendidikan Kesehatan Kepatuhan Minum Obat Terhadap Perubahan Gejala Halusinasi Pada Klienskizofrenia. Mental Health, 3(1).https://www.academia.edu/29589194/Pendidikan_Kesehatan Kepatuhan_Minum_Obat_Terhadap_Perubahan_Gejala_Halusinasi_Pada_P asien_Skizofrenia 
Putri, V. S. (2017). Pengaruh terapi aktivitas kelompok stimulasi persepsi halusinasi terhadap kemampuan mengontrol halusinasi pada pasien skizofrenia di ruang rawat inap arjuna rumah Sakit Jiwa Daerah Provinsi Jambi. Riset Informasi Kesehatan, 6(2), 174-183. https://doi.org/10.30644/rik.v6i2.95

Sutinah, S., Harkomah, I., \& Saswati, N. (2020). Terapi Aktivitas Kelompok Stimulasi Persepsi Sensori (Halusinasi) Pada Klien Halusinasi Di Rumah Sakit Jiwa Provinsi Jambi. Jurnal Pengabdian Masyarakat Dalam Kesehatan, 2(2). http://dx.doi.org/10.20473/jpmk.v2i2.19972

Yanti, D. A., Sitepu, A. L., Sitepu, K., \& Purba, W. N. B. (2020). Efektivitas Terapi Musik Klasik Terhadap Penurunan Tingkat Halusinasi Pada Pasien Halusinasi Pendengaran Di Rumah Sakit Jiwa Prof. Dr. M. Ildrem Medan Tahun 2020. Jurnal Keperawatan Dan Fisioterapi (Jkf), 3(1), 125-131. https://doi.org/10.35451/jkf.v3i1.527 